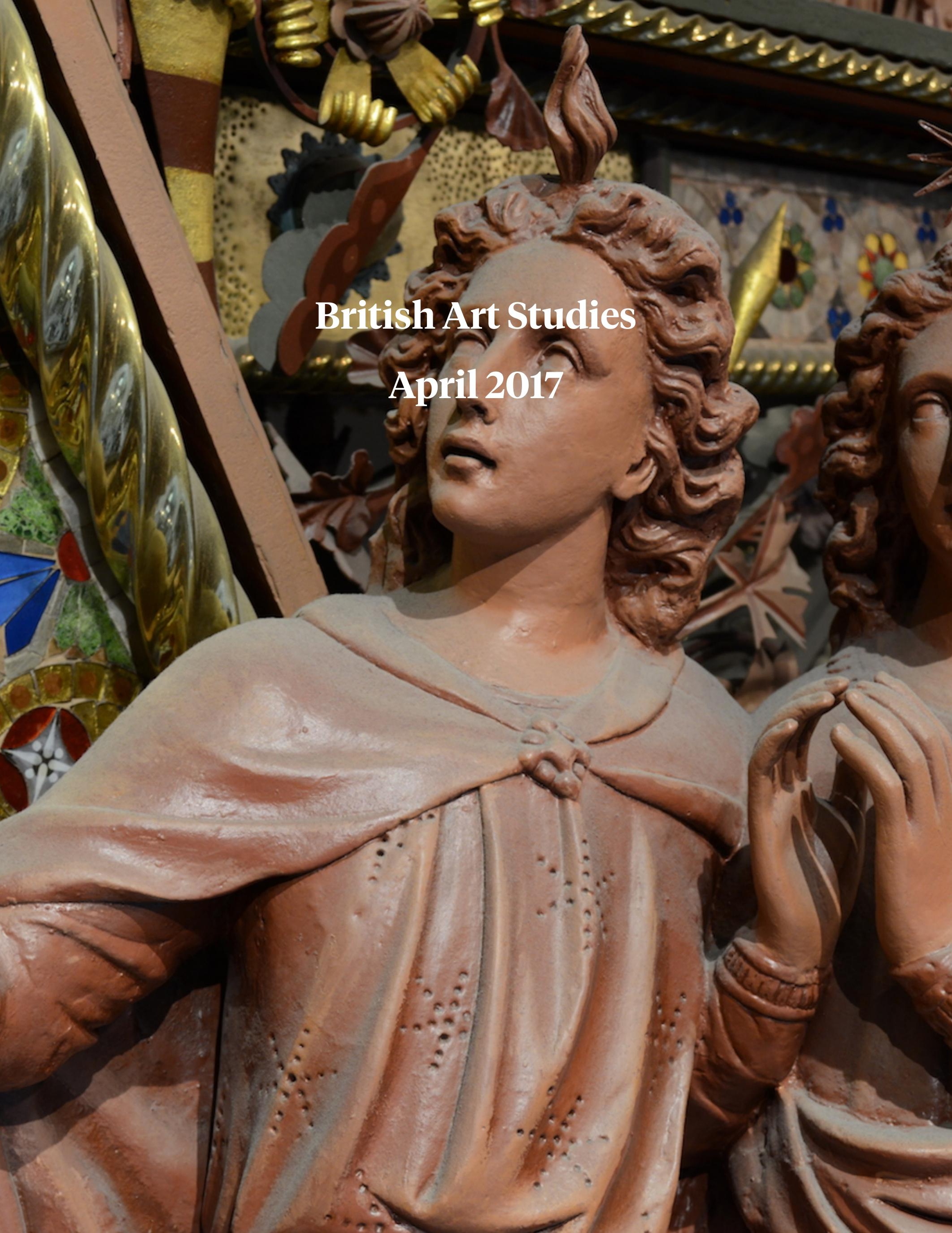


British Art Studies

Issue 5, published 17 April 2017

Cover image: Francis Alexander Skidmore and Sir George Gilbert Scott, Hereford Screen (detail), 1862, painted wrought and cast iron, brass, copper, timber, mosaics, and hardstones. Collection of the Victoria \& Albert Museum, London, Given by Herbert Art Gallery and Museum, Coventry (M.251:1 to 316-1984).. Digital image courtesy of Justin Underhill

PDF generated on 14 April 2022

Note: British Art Studies is a digital publication and intended to be experienced online and referenced digitally. PDFs are provided for ease of reading offline. Please do not reference the PDF in academic citations: we recommend the use of DOIs (digital object identifiers) provided within the online article. These unique alphanumeric strings identify content and provide a persistent link to a location on the internet. A DOI is guaranteed never to change, so you can use it to link permanently to electronic documents with confidence.

Published by:

Paul Mellon Centre 16 Bedford Square London, WC1B 3JA https://www.paul-mellon-centre.ac.uk

In partnership with:

Yale Center for British Art 1080 Chapel Street New Haven, Connecticut https://britishart.yale.edu

ISSN: 2058-5462

DOI: $10.17658 /$ issn.2058-5462

URL: https://www.britishartstudies.ac.uk

Editorial team: https://www.britishartstudies.ac.uk/about/editorial-team Advisory board: https://www.britishartstudies.ac.uk/about/advisory-board

Produced in the United Kingdom. 


\section{Contents}

Conserving and Restoring the Hereford Screen, Diana Heath 


\title{
Conserving and Restoring the Hereford screen
}

\author{
Diana Heath
}

8.

\section{Abstract}

In this film, the Victoria and Albert Museum's Head of Metals Conservation, Diana Heath, describes her involvement in the intricate conservation and restoration of the Hereford Screen over a number of years. From her first encounter with the screen in 1983, as its fragments arrived in the conservation studio packed in cases stuffed with straw, to the return of the screen to its former glory when it was installed as a whole object in the Metalwork Galleries above the main entrance to the Victoria and Albert Museum, Diana Heath guides us step-by-step through the restoration process of one of the most significant pieces of nineteenth-century metalwork.

\section{Authors}

Head of Metals Conservation at the Victoria and Albert Museum, London

\section{Acknowledgements}

The $V \& A$ is immensely grateful to all of those without whom the restoration of the screen would have been impossible.

The Heritage Lottery Fund financed half the conservation costs. Major donations were made by James and Lucilla Joll, John Scott and Mrs. Corinne Whiteley. Significant donations were made by the Michael Marks Charitable Trust, the Iris Foundation, the Headley Trust, the Monument Trust, the Crescent Trust, the Royal Commission for the Exhibition of 1851 and the Pilgrim Trust. Many other trusts and individuals contributed generously.

For other support the Museum thanks Rupert Harris, John Ronayne, Robert Thorne of Alan Baxter Associates and the Victorian Society; Plowden and Smith Ltd (Conservation/Restoration), Purcell Miller Tritton and Partners (Project Management), CJ Design (Lighting), and the V\&A team: Marian Campbell (Lead Curator/Project Manager), Eric Turner (Curator), Annette Wickham (Assistant Curator), and Diana Heath (Lead Conservator), along with the individual conservators and specialists who planned and carried out the work. 


\section{Cite as}

Diana Heath, "Conserving and Restoring the Hereford Screen", British Art Studies, Issue 5, https://dx.doi.org/10.17658/issn.2058-5462/issue-05/dheath 


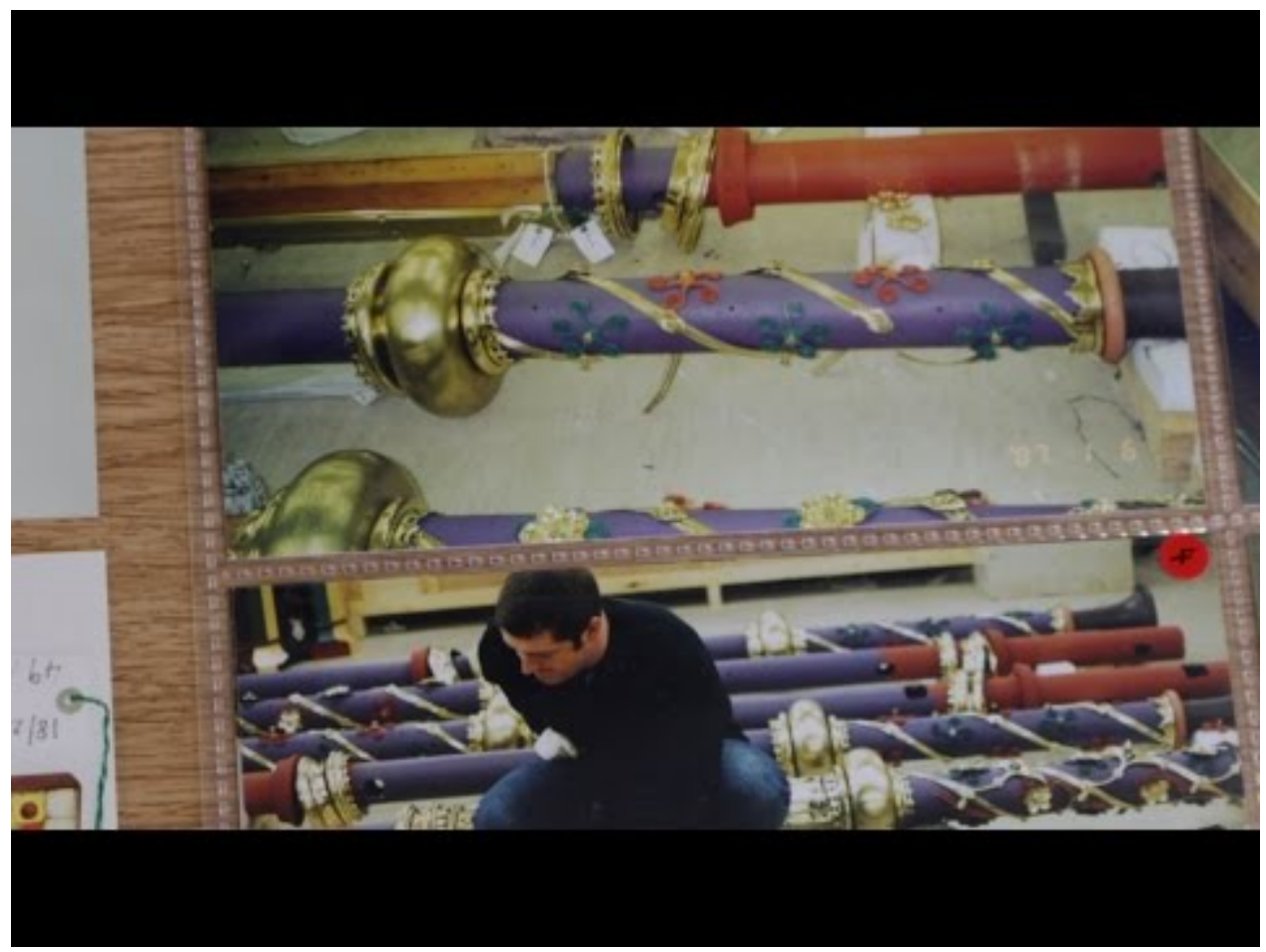

Watch Video

\section{Figure 1.}

Diana Heath, Conserving and Restoring the Hereford Screen, video essay, 2017. Digital image courtesy of Film by Jonathan Law

\section{Bibliography}

Cooper, Martin. "Recent Developments in Laser Cleaning", The Building Conservation Directory, 1997, pp. 122-124. Plowden and Smith. "Restoration of the Hereford Cathedral Chancel Screen, Manual no 3, Conservation Records of the Treatment of the Object and Techniques Adopted", unpublished report, April 2001.

Heath, Diana. "The Resurrection of the Hereford Screen", Conservation Journal, Issue 38, Summer 2001. http://www.vam.ac.uk/content/journals/conservation-journal/issue-38/the-resurrection-of-the-hereford-screen/ 


\section{Licensing}

The Publishers of British Art Studies are committed to supporting scholarship on British art and architecture of all periods. This publication is made available free of charge at https://www.britishartstudies.ac.uk. We ask users to identify the use of materials made available through this website and to provide an appropriate credit to the to the author and the publication, so that others may find and use our resources.

Except where otherwise noted, this work is licensed under a Creative Commons Attribution-NonCommercial 2.0 UK: England \& Wales Licence (CC BY-NC 2.0 UK). To view a copy of this license, visit https://creativecommons.org/licenses/by-nc/2.0/uk/ or send a letter to Creative Commons, PO Box 1866, Mountain View, CA 94042, USA.

The Publishers fully support the protection of intellectual property and are committed to complying with, and strictly adhering to, all applicable copyright law. In many cases, copyright or other proprietary rights may be held by individuals or entities other than, or in addition to, the Publishers. If a work or a photographic image is still protected by copyright, you must cite the relevant copyright information when using the image and comply with all other terms or restrictions that may be applicable to that material.

In some cases, exceptions to copyright that permit limited use of protected works without the permission of the copyright owner may have be applied. We are confident that we have carried out due diligence in our use of copyrighted material as required, but we apologise for any inadvertent infringement of rights.

Digital copies of resources are made accessible for research for one of the following reasons:

- they are in the public domain;

- the rights are owned by the Publishers;

- we make them accessible under an exception or limitation to UK copyright law, as outlined in the Copyright, Designs and Patents Act 1988 (as amended);

- we have permission to make them accessible;

- or, there are no known restrictions on use.

If you believe that we have made a mistake and wish for your material to be removed from our site, please contact us at copyright@paul-mellon-centre.ac.uk.

Please include the following information with your request:

- Name and contact information, including email address and phone number.

- Identification of the resource for consideration of removal. Providing URLs in your communication will help us locate content quickly.

- The reason for the request.

The Publishers respond promptly, normally within 21 business days. We may remove the resource from our site while we assess the validity of the request. Upon completion of the assessment, we will take appropriate action and communicate that action to you. 